\title{
Recovery of lithium from salt lake brine using a mixed ternary solvent extraction system consisting of TBP, $\mathrm{FeCl}_{3}$ and $\mathrm{P} 507$
}

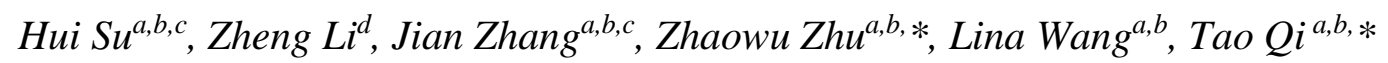

a National Engineering Laboratory for Hydrometallurgical Cleaner Production Technology,

Beijing 100190, China

${ }^{\mathrm{b}}$ Key Laboratory of Green Process and Engineering, Institute of Process Engineering,

Chinese Academy of Sciences, Beijing 100190, China

${ }^{\mathrm{c}}$ School of Chemistry and Chemical Engineering, University of Chinese Academy of

Sciences, Beijing 101408, China

${ }^{\mathrm{d}}$ Department of Chemistry, KU Leuven, Celestijnenlaan 200 F, B-3001 Heverlee, Belgium

\section{Corresponding author}

*Zhaowu Zhu. E-mail: zhwzhu@ipe.ac.cn, phone: +86 13311581061.

*Tao Qi. E-mail: tqi@ipe.ac.cn, phone: +86 13911132448. 
ABSTRACT: The consumption of lithium has been increasing rapidly due to its increasing application in lithium-ion batteries. The recovery of lithium from salt lake brines, which accounts for more than $70 \%$ of global lithium resources, has become increasingly studied; however, some challenges remain. In a previous study, a mixed ternary solvent extraction system consisting of TBP (tributyl phosphate), $\mathrm{FeCl}_{3}$ and P507 (2-ethylhexyl phosphonic acid mono-2-ethylhexyl ester) was developed. This newly developed system demonstrated good selectivity of $\mathrm{Li}$ over $\mathrm{Mg}$ and efficient lithium stripping simply using water. In the current study, to demonstrate its practical effectiveness, the $\mathrm{TBP} / \mathrm{FeCl}_{3} / \mathrm{P} 507$ system was tested with a real salt lake brine in both batch and multi-stage simulated counter-current modes. Detailed conditions for extraction, scrubbing and stripping were investigated. In the three-stage simulated counter-current extraction tests, the recovery of lithium reached $99.8 \%$, and in the three-stage simulated counter-current stripping tests, the obtained loaded strip liquor contained $\left(\mathrm{g} \cdot \mathrm{L}^{-1}\right)$ : $\mathrm{Li}, 20.9 ; \mathrm{Mg}, 2.2$; and $\mathrm{B}, 1.6$. During stripping, the $\mathrm{Fe}^{3+}$ remained fully in the organic phase, enabling the organic phase to be directly used in the next extraction without regeneration. The high lithium selectivity, lithium recovery and efficient lithium stripping with water of the above process promotes it as a cost-effective and sustainable method for recovering lithium from brines with high $\mathrm{Mg} / \mathrm{Li}$ ratios.

Keywords: ternary solvent extraction, lithium, salt lake brine, TBP, P507, stripping 


\section{Introduction}

Lithium-ion batteries (LIBs) have been widely used for electric vehicles and energy storage for renewable power due to their high energy density and light weight compared to other types of batteries (Etacheri et al., 2011; Li et al., 2014). Recently, these applications have significantly stimulated the rapid increase in lithium demand, particularly for battery-grade $\mathrm{Li}_{2} \mathrm{CO}_{3}$ to produce LIBs (Swain, 2017).

Salt lake brines and pegmatites are two main sources for the production of $\mathrm{Li}_{2} \mathrm{CO}_{3}$, with the former currently being dominant (Guo et al., 2018a; Kesler et al., 2012). A large amount of lithium is in salt lake brines in the Qaidam Basin on the Qinghai-Tibet Plateau of China, and these brines account for more than $80 \%$ of the total lithium resources that are available (Yu et al., 2013). However, most of these salt lake brines have high magnesium contents with very high $\mathrm{Mg} / \mathrm{Li}$ ratios (>50) ( $\mathrm{Li}$ et al., 2019; Song et al., 2017b), resulting in a large challenge for lithium recovery since $\mathrm{Li}$ and $\mathrm{Mg}$ are diagonally neighbouring elements on the periodic table with very similar physicochemical properties.

Several methods have been developed for lithium recovery from salt lake brines with high $\mathrm{Mg} / \mathrm{Li}$ ratios in China, including adsorption ( $\mathrm{Li}$ and $\mathrm{Liu}, 2017$; Li et al., 2015), calcination (Ren et al., 2013; Song et al., 2017a), membrane separation (Guo et al., 2018b; Zhang et al., 2017b), and solvent extraction (Nelli et al., 1970; Shi et al., 2019a; Zhou et al., 2020). Among them, the solvent extraction method based on a $\mathrm{TBP} / \mathrm{FeCl}_{3}$ system has many advantages for commercialization, such as high selectivity for $\mathrm{Li}$ over $\mathrm{Mg}$, a very simple process for Li recovery, low chemical consumption, and low operation and capital costs. The 
mechanism of extraction and stripping in the $\mathrm{TBP} / \mathrm{FeCl}_{3}$ system is provided as follows (Xiang et al., 2016; Xiang et al., 2017; Zhou et al., 2013; Zhou et al., 2012):

Extraction: $\quad \mathrm{Li}^{+}{ }_{(\mathrm{aq})}+\mathrm{FeCl}_{4}{ }_{(\mathrm{aq})}+x \mathrm{TBP}_{(\text {org })} \rightleftharpoons\left[\mathrm{Li}(\mathrm{TBP})_{x}\right]\left[\mathrm{FeCl}_{4}\right]_{(\text {org })}$

Stripping: $\quad \mathrm{H}^{+}{ }_{(\mathrm{aq})}+\left[\mathrm{Li}(\mathrm{TBP})_{x}\right]\left[\mathrm{FeCl}_{4}\right]_{(\mathrm{org})} \rightleftharpoons\left[\mathrm{H}(\mathrm{TBP})_{x}\right]\left[\mathrm{FeCl}_{4}\right]_{(\mathrm{org})}+\mathrm{Li}^{+}{ }_{(\mathrm{aq})}$

Regeneration: $\left[\mathrm{H}(\mathrm{TBP})_{x}\right]\left[\mathrm{FeCl}_{4}\right]_{(\text {org })}+\mathrm{NaOH}_{(\mathrm{aq})} \rightleftharpoons\left[\mathrm{Na}(\mathrm{TBP})_{x}\right]\left[\mathrm{FeCl}_{4}\right]_{(\text {org })}+\mathrm{H}_{2} \mathrm{O}_{(\mathrm{aq})}$

$\mathrm{Li}^{+}$is extracted into the organic phase by complexing with TBP after combining with $\left[\mathrm{FeCl}_{4}\right]^{-}$ to balance the charge (Eq. (1)). High concentrations of $\mathrm{HCl}$ (up to $6 \mathrm{~mol} \cdot \mathrm{L}^{-1}$ ) are commonly used for stripping to replace $\mathrm{Li}^{+}$with $\mathrm{H}^{+}$(Eq. (2)). The regeneration of the organic phase is required after stripping to neutralize excessive acid before it can be recycled to the extraction stage (Eq. (3)). The neutralization of the organic phase will consume a large amount of alkaline reagent and may also cause the loss of loaded $\mathrm{Fe}^{3+}$, resulting in a very complicated organic treatment step. Moreover, the use of high $\mathrm{HCl}$ concentrations can seriously corrode the equipment and cause the degradation of TBP. A series of problems associated with acid stripping are the main obstacle inhibiting the wide commercialization of solvent extraction methods based on the $\mathrm{TBP} / \mathrm{FeCl}_{3}$ system for lithium recovery from brines.

In recent years, many alternative anions, including $\left[\mathrm{PF}_{6}\right]^{-},\left[\mathrm{BPh}_{4}\right]^{-},\left[\mathrm{NTf}_{2}\right]^{-}$, and $\left[\mathrm{PW}_{12} \mathrm{O}_{40}\right]^{3-}$, either in the form of ionic liquids (ILs) or inorganic salts, have been found to be able to work in the same way as $\left[\mathrm{FeCl}_{4}\right]^{-}$for lithium extraction in combination with TBP (Gao et al., 2015; Kuz'min and Gudkova, 2015; Shi et al., 2015; Wang et al., 2019). However, ILs or inorganic salts containing these anions are expensive and suffer from recycling 
difficulties; hence, they are not suitable for industrialization.

To solve the problems associated with acid stripping of the $\mathrm{TBP} / \mathrm{FeCl}_{3}$ system, a novel mixed ternary solvent extraction system of $\mathrm{TBP} / \mathrm{FeCl}_{3} / \mathrm{P} 507$ was developed in our previous study, which significantly enhanced lithium stripping using only water through the regulation of $\mathrm{Fe}^{3+}$ coordination (Su et al., 2020a). The extraction of lithium into the organic phase from brines with a high $\mathrm{Mg}$ content still occurs by forming the $\left[\mathrm{Li}(\mathrm{TBP})_{2}\right]\left[\mathrm{FeCl}_{4}\right]$ complex, in which P507 is not involved in the coordination. When $\mathrm{Li}^{+}$is stripped by water from the loaded organic phase, P507 and TBP synergistically coordinate with $\mathrm{Fe}^{3+}$ in the form of $\left[\mathrm{FeCl}_{2} \mathrm{~L} \cdot(\mathrm{HL}) \cdot 2 \mathrm{TBP}\right]$ (HL denotes P507), leading to efficient stripping of lithium due to the broken structure of $\left[\mathrm{Li}(\mathrm{TBP})_{2}\right]\left[\mathrm{FeCl}_{4}\right]$; furthermore, $\mathrm{Fe}^{3+}$ remains in the organic phase for recycling. Compared to the $\mathrm{TBP} / \mathrm{FeCl}_{3}$ system, water is used as the stripping agent in the $\mathrm{TBP} / \mathrm{FeCl}_{3} / \mathrm{P} 507$ system instead of a high concentration of $\mathrm{HCl}$, enabling the direct recycling of the organic phase without regeneration and significantly lowering the cost of lithium recovery from salt lake brines.

In this study, a novel $\mathrm{TBP} / \mathrm{FeCl}_{3} / \mathrm{P} 507$ system was applied for the recovery of lithium from a real brine obtained from East Tajinar Salt Lake in China. Various effect factors, including the concentrations of TBP and P507, acidities, organic to aqueous phase ratios $(\mathrm{O} / \mathrm{A})$, temperature and shaking time, on lithium recovery were investigated and optimized. Finally, a nine-stage simulated counter-current process for effective lithium recovery was proposed and tested.

\section{Experimental}




\subsection{Materials}

$\mathrm{FeCl}_{3}(>98 \%), \mathrm{MgCl}_{2}(>99 \%)$ and $\mathrm{HCl}(37 \mathrm{wt} \%)$ were purchased from Beijing Chemical Works. Tributyl phosphate (> 98.5\%) and 2-ethylhexyl phosphonic acid mono-2-ethylhexyl ester (> 95\%) were provided by Shanghai Rare Earth Chemical Co., Ltd. Sulfonated kerosene $(\mathrm{MW}=142-254)$ was purchased from Sinopharm Group Chemical Reagent Co. Organic phases were prepared by mixing TBP and P507 with kerosene according to the required volume ratio. The treated East Tajinar Salt Lake brine was obtained from Qinghai Salt Lake BYD Resources Development Co., Ltd. and subjected to acidification - crystallization for B removal before lithium extraction. $\mathrm{HCl}$ (37 wt $\%$ ) was added to the brine (the volume ratio of $\mathrm{HCl}$ and brine was $1 / 20$ ) and shaken at $50{ }^{\circ} \mathrm{C}$ for 30 min. After settling for $3 \mathrm{~h}$, the $\mathrm{H}_{3} \mathrm{BO}_{3}$ precipitate was filtered, and the filtrate was used as the feed solution for the study. The composition of the feed solution is shown in Table 1.

Table 1. Composition of the treated East Tajinar Salt Lake brine after the removal of B.

\begin{tabular}{ccccccc}
\hline Component & $\mathrm{Li}^{+}$ & $\mathrm{Mg}^{2+}$ & $\mathrm{B}$ & $\mathrm{Na}^{+}$ & $\mathrm{K}^{+}$ & $\mathrm{pH}$ \\
\hline Concentration $/\left(\mathrm{g} \cdot \mathrm{L}^{-1}\right)$ & 5.02 & 108.10 & 2.23 & 1.31 & 0.59 & 0.86 \\
\hline
\end{tabular}

\subsection{Methods}

$\mathrm{FeCl}_{3}$ was weighed and dissolved in a saturated $\mathrm{MgCl}_{2}$ solution and mixed with the prepared organic phase consisting of TBP, P507 and kerosene in $250 \mathrm{~mL}$ hexagonal jars using a mechanical shaker (HD-100B, Jintan Yineng, China) with an O/A ratio of 1:1 (100 $\mathrm{mL} / 100 \mathrm{~mL}$ ) at $20 \pm 2{ }^{\circ} \mathrm{C}$ for $20 \mathrm{~min}$ to preload $\mathrm{Fe}^{3+}$. After shaking for $20 \mathrm{~min}$, the mixtures were allowed to settle for $30 \mathrm{~min}$ to separate the phases. The $\mathrm{Fe}^{3+}$-loaded organic phase was 
then mixed with the treated East Tajinar Salt Lake brine after some of the B was removed in $150 \mathrm{~mL}$ hexagonal jars, shaken with designated $\mathrm{O} / \mathrm{A}$ ratios $(80 \mathrm{~mL} /-\mathrm{mL})$ at $20 \pm 2{ }^{\circ} \mathrm{C}$ for 20 min, and then allowed to settle for 30 min to separate the phases. Scrubbing and stripping experiments were carried out using the same method. The O/A ratios were varied by varying the organic and aqueous volumes accordingly. Aqueous samples were taken from the bottom phases using a syringe with a tube extender for the determination of metal and $\mathrm{H}^{+}$ concentrations. The concentrations of $\mathrm{Li}^{+}, \mathrm{Mg}^{2+}$ and $\mathrm{B}$ in the organic phases were determined after stripping with $6 \mathrm{~mol} \cdot \mathrm{L}^{-1} \mathrm{HCl}$, and $\mathrm{Fe}^{3+}$ in the organic phases was calculated by mass balance based on its aqueous concentration $\left(\mathrm{Fe}^{3+}\right.$ cannot be effectively stripped by $6 \mathrm{~mol} \cdot \mathrm{L}^{-1}$ $\mathrm{HCl})$.

The percentage extraction $\% E$, percentage stripping $\% S$, distribution ratio $D$ and separation factor $\alpha$ are defined as follows:

$$
\begin{gathered}
\% E=\frac{C_{\text {org }} \cdot V_{\text {org }}}{C_{\text {org }} \cdot V_{\text {org }}+C_{\text {aq }} \cdot V_{\text {aq }}} \times 100 \% \\
\% S=\frac{C_{\text {org }}-C_{\text {org,s }}}{C_{\text {org }}} \times 100 \% \\
D=\frac{C_{\text {org }}}{C_{\text {aq }}}
\end{gathered}
$$

where $C_{\text {org }}$ and $C_{\text {aq }}$ and $V_{\text {org }}$ and $V_{\text {aq }}$ are the element equilibrium concentrations and volumes of the organic and aqueous phases, respectively, and $C_{\mathrm{org}, \mathrm{s}}$ is the element equilibrium concentration in the stripped organic phase. 


\subsection{Simulated counter-current test}

The procedures for the three-stage simulated counter-current test (SCT) are shown in Fig. 1. An SCT for lithium extraction was carried out at an O/A ratio of 4:1 until 11 contact rows were completed where an extraction equilibrium was reached (the change in metal concentration was insignificant). Each contact was shaken for $20 \mathrm{~min}$, and the phase separation was accelerated by centrifugation (TG16, Shanghai Lu Xiangyi, China) for 3 min at $3000 \mathrm{rpm}$. The samples were taken from the last contact rows of row 10 and row 11 to determine the concentrations of $\mathrm{Li}^{+}, \mathrm{Mg}^{2+}, \mathrm{Fe}^{3+}, \mathrm{B}$ and $\mathrm{H}^{+}$. The SCTs for the scrubbing and stripping operations with different $\mathrm{O} / \mathrm{A}$ ratios were also carried out using the same method.

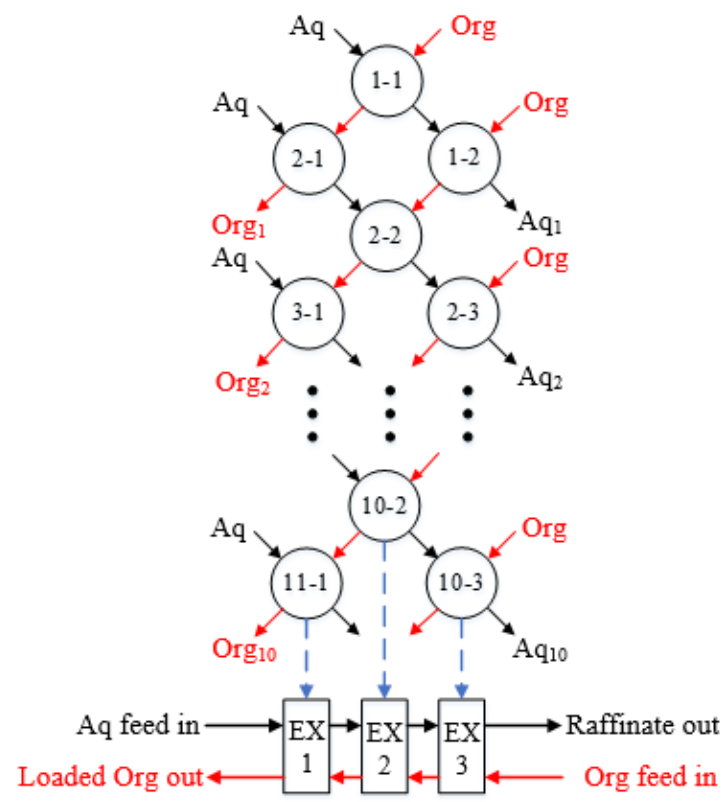

Fig. 1. Diagram showing the procedure of the three-stage SCT. The organic phase (Org), aqueous phase (Aq) and extraction stages (EX) are abbreviated in the scheme.

\subsection{Analysis}

The concentrations in the aqueous samples were determined by inductively coupled 
plasma-optical emission spectroscopy (ICP-OES, Optima 5300V, Pekin-Elmer, USA) after dilution to a proper concentration range. The $\mathrm{H}^{+}$concentration was determined by titration using a standard $\mathrm{NaOH}$ solution with a masking solution containing saturated $\mathrm{K}_{2} \mathrm{SO}_{4}$ and 0.2 $\mathrm{mol} \cdot \mathrm{L}^{-1} \mathrm{C}_{2} \mathrm{H}_{2} \mathrm{O}_{4}$ (Su et al., 2020b). The masking solution was used mainly to eliminate the effect of iron(III) hydrolysis by producing extra $\mathrm{H}^{+}$, which can also prevent the reaction of $\mathrm{Mg}^{2+}$ with $\mathrm{NaOH}$ (Pakalns, 1981; Starke, 1963).

\section{Results and discussion}

\subsection{Batch tests for lithium extraction}

\subsection{1. $\mathrm{Fe}^{3+}$ pre-loading}

Previous studies have shown that the optimum range of the Fe/Li molar ratio is $1.3-1.7$ for lithium extraction (Shi et al., 2019b). Because the concentration of $\mathrm{Li}^{+}$in the salt lake brine can be as high as $5.02 \mathrm{~g} \cdot \mathrm{L}^{-1}$ (Table 2), a high $\mathrm{Fe}^{3+}$ concentration of $52-68 \mathrm{~g} \cdot \mathrm{L}^{-1}$ will be required to reach that ratio range if $\mathrm{Fe}^{3+}$ is added into the brine and co-extracted. The addition of iron salt could increase the brine viscosity and result in precipitation by over-saturation or metal hydrolysis. In this study, $\mathrm{Fe}^{3+}$ was pre-loaded in the organic phase in contact with the $\mathrm{FeCl}_{3}$ solution at a given concentration, and a high $\mathrm{Fe} / \mathrm{Li}$ molar ratio was achieved by the $\mathrm{Fe}^{3+}$ concentration in the organic phase and by a large $\mathrm{O} / \mathrm{A}$ ratio.

To obtain the maximum $\mathrm{Fe}^{3+}$ loading of the organic phase, different organic phases consisting of TBP and P507 diluted in kerosene were placed in contact with the $\mathrm{FeCl}_{3}$ solution containing various $\mathrm{Fe}^{3+}$ concentrations and near-saturated $\mathrm{MgCl}_{2}$ at an $\mathrm{O} / \mathrm{A}$ ratio of 
1:1. The performance of the phase separation and extraction of $\mathrm{Fe}^{3+}$ are shown in Table 2 . The maximum $\mathrm{Fe}^{3+}$ loading was $14 \mathrm{~g} \cdot \mathrm{L}^{-1}$ with the organic phase consisting of $40 \mathrm{vol} \% \mathrm{TBP}$ and 30 vol\% P507 without forming a third phase. Low concentrations of TBP or P507 led to the formation of a third phase, even with an $\mathrm{Fe}^{3+}$ loading of $14 \mathrm{~g} \cdot \mathrm{L}^{-1}$. This result was because the concentration of extracted species $\left[\mathrm{Mg}(\mathrm{TBP})_{2}\right]\left[\mathrm{FeCl}_{4}\right]_{2}$ in the organic phase had reached saturation, and some of them could not be dissolved (Shi et al., 2019a; Zhang et al., 2012). Therefore, the organic system consisting of $40 \mathrm{vol} \%$ TBP and $30 \mathrm{vol} \%$ P507 or higher concentrations of TBP and P507 in kerosene pre-loaded with $14 \mathrm{~g} \cdot \mathrm{L}^{-1} \mathrm{Fe}^{3+}$ was used in the following experiments. To obtain a proper $\mathrm{Fe} / \mathrm{Li}$ molar ratio in the system of the $\mathrm{Fe}^{3+}$ pre-loaded organic phase and the feed brine, an O/A ratio of 4:1 was used with a desirable $\mathrm{Fe} / \mathrm{Li}$ molar ratio of approximately 1.3 in the tests unless the tests were on the O/A ratio effect.

Table 2. $\mathrm{Fe}^{3+}$ pre-loading and phase separation with various organic phases.

\begin{tabular}{ccccc}
\hline $\begin{array}{c}\mathrm{Fe}^{3+} \text { in feed } \\
\text { solution }\left(\mathrm{g} \cdot \mathrm{L}^{-1}\right)\end{array}$ & {$[\mathrm{TBP}](\mathrm{vol} \%)$} & {$[\mathrm{P} 507](\mathrm{vol} \%)$} & Phase separation & $\begin{array}{c}\mathrm{Fe}^{3+} \text { extraction } \\
(\%)\end{array}$ \\
\hline 8 & 40 & 30 & Good phase & 100 \\
10 & 40 & 30 & Good phase & 100 \\
12 & 40 & 30 & Good phase & 100 \\
14 & 40 & 30 & Good phase & 99.99 \\
16 & 40 & 30 & Third phase & 98.95 \\
14 & 40 & 20 & Third phase & 99.93 \\
14 & 30 & 30 & Third phase & 99.91 \\
\hline
\end{tabular}

\subsubsection{Effect of the TBP concentration}

Organic phases containing various TBP (vol\%) concentrations and 30 vol\% P507 
pre-loaded with approximately $14 \mathrm{~g} \cdot \mathrm{L}^{-1} \mathrm{Fe}^{3+}$ in kerosene were placed in contact with the brine to extract lithium at an $\mathrm{O} / \mathrm{A}$ ratio of $4: 1$. As the pre-loaded $\mathrm{Fe}^{3+}$ was conducted by the saturated $\mathrm{MgCl}_{2}$ solution, some $\mathrm{Mg}^{2+}$ was also co-extracted to the $\mathrm{Fe}^{3+}$-loaded organic phase. The composition of the pre-loaded $\mathrm{Fe}^{3+}$ organic phase and the main elements extracted into the organic phase after contact with the brine are shown in Table 3. The effect of TBP concentration on the extraction of these elements is shown in Fig. 2.

The $\mathrm{Li}^{+}$extraction increased slowly with increasing TBP concentration, and it was 85.8 and $90.8 \%$ at TBP concentrations of 40 and $60 \mathrm{vol} \%$, respectively. The concentration of $\mathrm{Li}^{+}$ in the organic phase only increased by $0.07 \mathrm{~g} \cdot \mathrm{L}^{-1}$ as the TBP concentration increased from 40 to $60 \mathrm{vol} \% \mathrm{Li}^{+}$was extracted in the form of $\left[\mathrm{Li}(\mathrm{TBP})_{2}\right]\left[\mathrm{FeCl}_{4}\right]$, and $\mathrm{P} 507$ was not involved in this coordination (Su et al., 2020a). The concentration of pre-loaded $\mathrm{Fe}^{3+}$ in the organic phase remained almost unchanged after lithium extraction, indicating that no $\mathrm{Fe}^{3+}$ was lost in the raffinate during lithium extraction. The concentration of pre-loaded $\mathrm{Mg}^{2+}$ in the organic phase increased with increasing TBP concentration due to the formation of the $\left[\mathrm{Mg}(\mathrm{TBP})_{2}\right]\left[\mathrm{FeCl}_{4}\right]_{2}$ complex (Shi et al., 2019a; Shi et al., 2018), and it decreased after lithium extraction. This result was because $\mathrm{Mg}^{2+}$ was partially replaced by $\mathrm{Li}^{+}$in the brine; therefore, the extraction of $\mathrm{Li}^{+}$was superior to that of $\mathrm{Mg}^{2+}$. The extraction of $\mathrm{B}$ increased rapidly with increasing TBP concentration and reached a maximum of $51.1 \%$ at $60 \mathrm{vol} \%$ TBP. Because $\mathrm{B}$ was present in the form of $\mathrm{H}_{3} \mathrm{BO}_{3}$ in the brine after acidification and filtration, it might be extracted by forming weak hydrogen bonds between the $-\mathrm{OH}$ in $\mathrm{H}_{3} \mathrm{BO}_{3}$ and $-\mathrm{P}=\mathrm{O}$ in TBP (Cengeloglu et al., 2007; Xiang et al., 2016). To maintain a high lithium extraction and decrease the extraction of impurity elements, 40 vol\% TBP was selected as the 
optimum concentration in the following study.

Table 3. Compositions of the pre-loaded organic phases and the elements extracted after coming into contact with the brine.

\begin{tabular}{|c|c|c|c|c|c|c|}
\hline \multirow[b]{2}{*}{$\begin{array}{l}{[\mathrm{TBP}]} \\
(\mathrm{vol} \%)\end{array}$} & \multicolumn{2}{|c|}{$\begin{array}{c}\text { Pre-loaded organic } \\
\text { phase }\end{array}$} & \multicolumn{4}{|c|}{ Organic phase after extraction } \\
\hline & $\begin{array}{c}{\left[\mathrm{Fe}^{3+}\right]_{\text {org }}} \\
\left(\mathrm{g} \cdot \mathrm{L}^{-1}\right)\end{array}$ & $\begin{array}{l}{\left[\mathrm{Mg}^{2+}\right]_{\mathrm{org}}} \\
\left(\mathrm{g} \cdot \mathrm{L}^{-1}\right)\end{array}$ & $\begin{array}{c}{\left[\mathrm{Fe}^{3+}\right]_{\text {org }}} \\
\left(\mathrm{g} \cdot \mathrm{L}^{-1}\right)\end{array}$ & $\begin{array}{c}{\left[\mathrm{Mg}^{2+}\right]_{\text {org }}} \\
\left(\mathrm{g} \cdot \mathrm{L}^{-1}\right)\end{array}$ & $\begin{array}{l}{\left[\mathrm{Li}^{+}\right]_{\text {org }}} \\
\left(\mathrm{g} \cdot \mathrm{L}^{-1}\right)\end{array}$ & $\begin{array}{l}{[\mathrm{B}]_{\text {org }}} \\
\left(\mathrm{g} \cdot \mathrm{L}^{-1}\right)\end{array}$ \\
\hline 40 & 13.39 & 3.63 & 13.39 & 2.13 & 1.13 & 0.13 \\
\hline 45 & 13.39 & 4.35 & 13.39 & 2.99 & 1.12 & 0.16 \\
\hline 50 & 13.39 & 5.14 & 13.39 & 3.60 & 1.05 & 0.19 \\
\hline 55 & 13.39 & 5.70 & 13.39 & 5.10 & 1.17 & 0.24 \\
\hline 60 & 13.39 & 6.15 & 13.39 & 5.88 & 1.20 & 0.28 \\
\hline
\end{tabular}

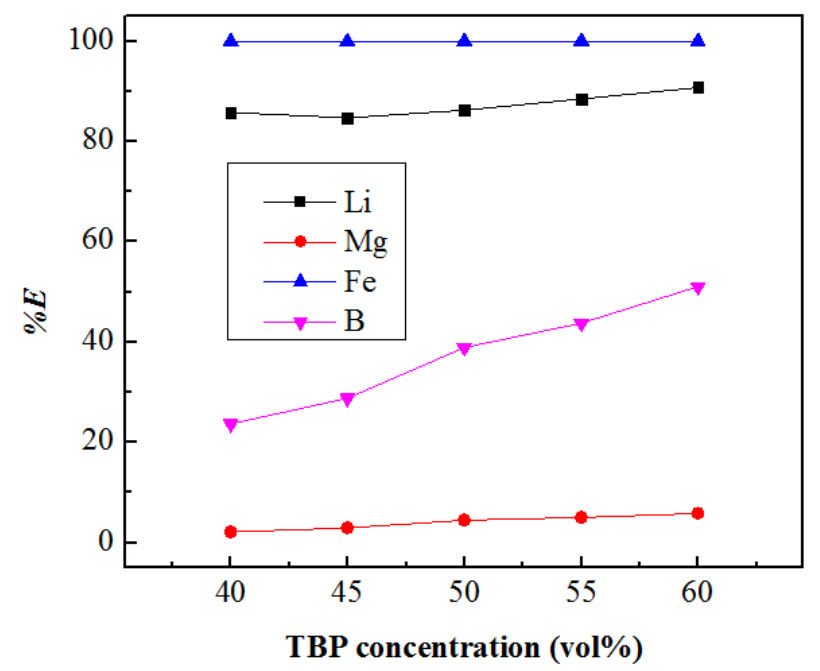

Fig. 2. Effect of the TBP concentration on the extraction of elements.

\subsubsection{Effect of the P507 concentration}

Organic phases containing various P507 (vol\%) concentrations and 40 vol\% TBP pre-loaded with approximately $14 \mathrm{~g} \cdot \mathrm{L}^{-1} \mathrm{Fe}^{3+}$ in kerosene were placed in contact with the 
brine to extract lithium at an $\mathrm{O} / \mathrm{A}$ ratio of $4: 1$. The composition of the pre-loaded $\mathrm{Fe}^{3+}$ organic phases and the main elements extracted into the organic phase after contact with the brine are shown in Table 4. The effect of the P507 concentration on the extraction of these elements is shown in Fig. 3.

It was found that the extraction of $\mathrm{Li}^{+}$was slightly suppressed by P507 since the extraction of $\mathrm{Li}^{+}$slightly decreased with increasing P507 concentration, and it remained 84.9\% at a P507 concentration of $30 \mathrm{vol} \%$. The pre-loaded $\mathrm{Fe}^{3+}$ remained unchanged during the lithium extraction, indicating that P507 had no obvious effect on the $\mathrm{Fe}^{3+}$ loaded in the organic phase. The concentration of $\mathrm{Mg}^{2+}$ in the organic phase slightly increased with increasing P507 concentration, indicating that P507 could promote the extraction of $\mathrm{Mg}^{2+}$. However, $\mathrm{Mg}^{2+}$ extraction was still at a low level in the tested concentration range of the P507 addition; therefore, good separation of $\mathrm{Li}^{+}$and $\mathrm{Mg}^{2+}$ can be maintained. $\mathrm{Mg}^{2+}$ extracted into the organic phase is still mainly in the form of $\left[\mathrm{Mg}(\mathrm{TBP})_{2}\right]\left[\mathrm{FeCl}_{4}\right]_{2}$, since $\mathrm{FeCl}_{4}{ }^{-}$is the main component in high concentrations of $\mathrm{Cl}^{-}$(Su et al., 2020b; Zhou et al., 2013). The concentration of $\mathrm{Mg}^{2+}$ in the pre-loaded organic phase decreased during $\mathrm{Li}^{+}$extraction, also suggesting that some $\mathrm{Mg}^{2+}$ was substituted by $\mathrm{Li}^{+}$due to its stronger extraction potential. The extraction of B increased very slightly with an increasing P507 concentration and did not have a significant effect on lithium recovery. Taking all effects into consideration, 30 vol\% P507 was chosen for high lithium extraction and low impurity extraction.

Table 4. Compositions of the pre-loaded organic phases and the elements extracted after coming into contact with the brine. 


\begin{tabular}{|c|c|c|c|c|c|c|}
\hline \multirow[b]{2}{*}{$\begin{array}{l}{[\mathrm{P} 507]} \\
(\mathrm{vol} \%)\end{array}$} & \multicolumn{2}{|c|}{$\begin{array}{l}\text { Pre-loaded organic } \\
\text { phase }\end{array}$} & \multicolumn{4}{|c|}{ Organic phase after extraction } \\
\hline & $\begin{array}{c}{\left[\mathrm{Fe}^{3+}\right]_{\text {org }}} \\
\left(\mathrm{g} \cdot \mathrm{L}^{-1}\right)\end{array}$ & $\begin{array}{l}{\left[\mathrm{Mg}^{2+}\right]_{\mathrm{org}}} \\
\left(\mathrm{g} \cdot \mathrm{L}^{-1}\right)\end{array}$ & $\begin{array}{c}{\left[\mathrm{Fe}^{3+}\right]_{\text {org }}} \\
\left(\mathrm{g} \cdot \mathrm{L}^{-1}\right)\end{array}$ & $\begin{array}{l}{\left[\mathrm{Mg}^{2+}\right]_{\text {org }}} \\
\left(\mathrm{g} \cdot \mathrm{L}^{-1}\right)\end{array}$ & $\begin{array}{l}{\left[\mathrm{Li}^{+}\right]_{\mathrm{org}}} \\
\left(\mathrm{g} \cdot \mathrm{L}^{-1}\right)\end{array}$ & $\begin{array}{l}{[\mathrm{B}]_{\mathrm{org}}} \\
\left(\mathrm{g} \cdot \mathrm{L}^{-1}\right)\end{array}$ \\
\hline 30 & 13.39 & 3.66 & 13.39 & 2.40 & 1.09 & 0.11 \\
\hline 35 & 13.39 & 3.70 & 13.39 & 2.59 & 1.05 & 0.11 \\
\hline 40 & 13.39 & 3.67 & 13.39 & 2.90 & 1.01 & 0.12 \\
\hline 45 & 13.39 & 4.35 & 13.39 & 3.21 & 0.97 & 0.13 \\
\hline 50 & 13.39 & 4.83 & 13.39 & 3.33 & 0.93 & 0.14 \\
\hline
\end{tabular}

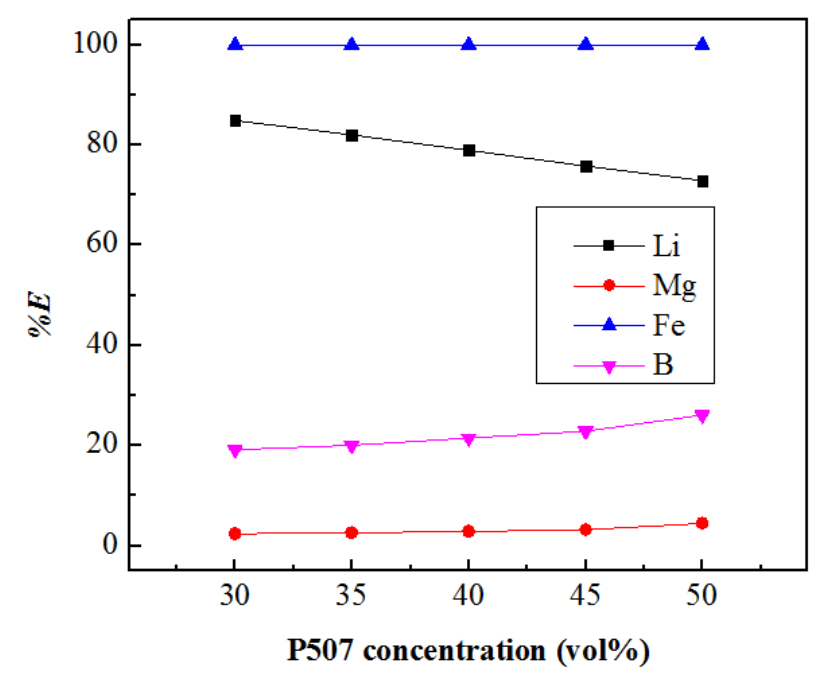

Fig. 3. Effect of the P507 concentration on the extraction of elements.

\subsubsection{Effect of the HCl concentration}

$\mathrm{H}^{+}$had a stronger binding capacity with the $\left[\mathrm{FeCl}_{4} \cdot 2 \mathrm{TBP}\right]^{-}$species than $\mathrm{Li}^{+}$and $\mathrm{Mg}^{2+}$ (Su et al., 2020b). Therefore, the effect of $\mathrm{HCl}$ concentration on lithium extraction was studied. Organic phases containing 40 vol\% TBP and 30 vol\% P507 pre-loaded with approximately $14 \mathrm{~g} \cdot \mathrm{L}^{-1} \mathrm{Fe}^{3+}$ and different concentrations of $\mathrm{HCl}$ in kerosene were placed in contact with the brine to extract lithium at an $\mathrm{O} / \mathrm{A}$ ratio of $4: 1$. The composition of the pre-loaded $\mathrm{Fe}^{3+}$ organic phases and the main elements extracted into the organic phase after 
coming into contact with the brine are shown in Table 5. The effect of $\mathrm{HCl}$ concentration on the extraction of these elements is shown in Fig. 4.

The extraction of $\mathrm{Li}^{+}$decreased from 84.5 to $67.4 \%$ with the increase in $\mathrm{HCl}$ concentration from 0 to $0.25 \mathrm{~mol} \cdot \mathrm{L}^{-1}$, indicating that $\mathrm{H}^{+}$could adversely affect lithium extraction. This result was because $\mathrm{H}^{+}$could form $\left[\mathrm{H}(\mathrm{TBP})_{2}\right]\left[\mathrm{FeCl}_{4}\right]$ and competed with lithium extraction. The concentration of pre-loaded $\mathrm{Fe}^{3+}$ in the organic phase was almost unchanged with the increase in $\mathrm{HCl}$ concentration during the lithium extraction. The pre-loaded $\mathrm{Mg}^{2+}$ in the organic phase decreased with the increase in $\mathrm{HCl}$ concentration, which was attributed to the competitive extraction of $\mathrm{H}^{+}$and $\mathrm{Mg}^{2+}$, and its concentration decreased to some extent after coming into contact with the brine, suggesting that $\mathrm{Li}^{+}$could replace $\mathrm{Mg}^{2+}$ in the organic phase over a wide acidic $\mathrm{pH}$ range. The extraction of $\mathrm{B}$ also decreased slightly with the increase in $\mathrm{HCl}$ concentration without a significant effect on the lithium extraction. High lithium extraction could be obtained at low $\mathrm{HCl}$ concentrations; therefore, the $\mathrm{HCl}$ concentration should be maintained as low as possible to favour lithium extraction.

Table 5. Compositions of the pre-loaded organic phases and the elements extracted after coming into contact with the brine.

\begin{tabular}{|c|c|c|c|c|c|c|}
\hline \multirow[b]{2}{*}{$\begin{array}{c}{[\mathrm{HCl}]} \\
\left(\mathrm{mol} \cdot \mathrm{L}^{-1}\right)\end{array}$} & \multicolumn{2}{|c|}{$\begin{array}{l}\text { Pre-loaded organic } \\
\text { phase }\end{array}$} & \multicolumn{4}{|c|}{ Organic phase after extraction } \\
\hline & $\begin{array}{c}{\left[\mathrm{Fe}^{3+}\right]_{\text {org }}} \\
\left(\mathrm{g} \cdot \mathrm{L}^{-1}\right)\end{array}$ & $\begin{array}{l}{\left[\mathrm{Mg}^{2+}\right]_{\text {org }}} \\
\left(\mathrm{g} \cdot \mathrm{L}^{-1}\right)\end{array}$ & $\begin{array}{c}{\left[\mathrm{Fe}^{3+}\right]_{\text {org }}} \\
\left(\mathrm{g} \cdot \mathrm{L}^{-1}\right)\end{array}$ & $\begin{array}{l}{\left[\mathrm{Mg}^{2+}\right]_{\mathrm{org}}} \\
\left(\mathrm{g} \cdot \mathrm{L}^{-1}\right)\end{array}$ & $\begin{array}{l}{\left[\mathrm{Li}^{+}\right]_{\text {org }}} \\
\left(\mathrm{g} \cdot \mathrm{L}^{-1}\right)\end{array}$ & $\begin{array}{l}{[\mathrm{B}]_{\mathrm{org}}} \\
\left(\mathrm{g} \cdot \mathrm{L}^{-1}\right)\end{array}$ \\
\hline 0 & 13.10 & 4.17 & 13.10 & 2.80 & 1.02 & 0.09 \\
\hline 0.05 & 13.07 & 4.30 & 13.07 & 2.54 & 0.98 & 0.07 \\
\hline
\end{tabular}




\begin{tabular}{lllllll}
\hline 0.10 & 13.06 & 3.85 & 13.06 & 2.26 & 0.94 & 0.07 \\
0.15 & 13.05 & 3.43 & 13.05 & 2.06 & 0.90 & 0.07 \\
0.20 & 13.05 & 2.78 & 13.05 & 1.75 & 0.85 & 0.06 \\
0.25 & 13.05 & 2.63 & 13.05 & 1.43 & 0.82 & 0.06 \\
\hline
\end{tabular}

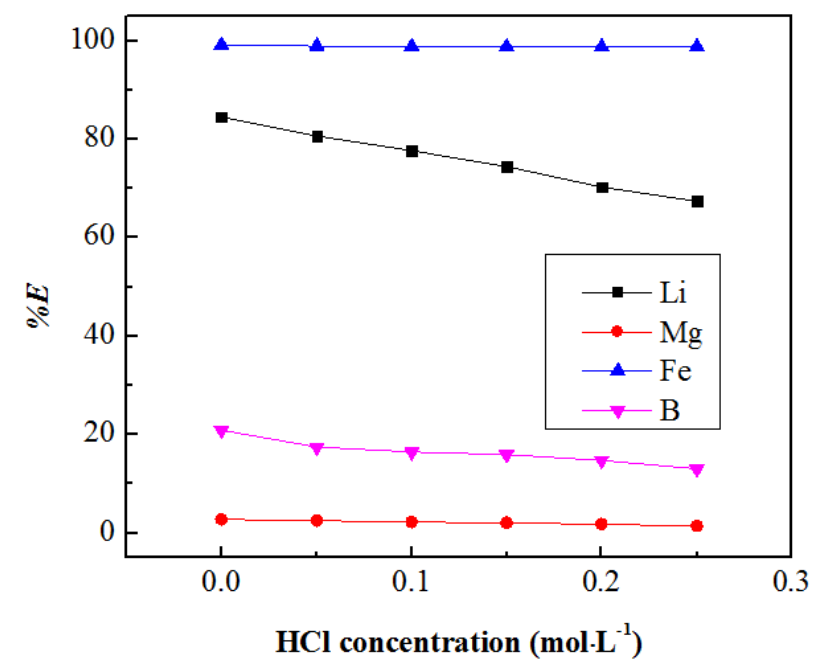

Fig. 4. Effect of the $\mathrm{HCl}$ concentration on the extraction of elements.

\subsubsection{Effect of the phase ratio $(\mathrm{O} / \mathrm{A})$}

To investigate the effect of the $\mathrm{O} / \mathrm{A}$ ratio on lithium extraction, a pre-loaded $\mathrm{Fe}^{3+}$ organic phase containing $40 \mathrm{vol} \%$ TBP, $30 \mathrm{vol} \% \mathrm{P} 507,13.35 \mathrm{~g} \cdot \mathrm{L}^{-1} \mathrm{Fe}^{3+}$ and $3.65 \mathrm{~g} \cdot \mathrm{L}^{-1} \mathrm{Mg}^{2+}$ was prepared (this pre-loaded organic phase was also used in the following tests) to come into contact with the brine at different O/A ratios, with the results shown in Fig. 5. The $\mathrm{Li}^{+}$ extraction increased rapidly with the increase in the $\mathrm{O} / \mathrm{A}$ ratio, but its concentration in the organic phase decreased due to the increase in organic volume. The $\mathrm{Li}^{+}$extraction was $84.0 \%$, and its concentration in the organic phase was $1.04 \mathrm{~g} \cdot \mathrm{L}^{-1}$ at an $\mathrm{O} / \mathrm{A}$ ratio of $4: 1$. High $\mathrm{Fe}^{3+}$ extraction (Fig. 5a) and an insignificant concentration change in the loaded organic phase (Fig. 5b) also show that $\mathrm{Fe}^{3+}$ was completely maintained in the organic phase during lithium 
extraction. The extraction of $\mathrm{Mg}^{2+}$ and its concentration in the organic phase both increased with the increase in the $\mathrm{O} / \mathrm{A}$ ratio. This result could be attributed to the fact that the concentration of $\mathrm{Mg}^{2+}$ in the brine was very high, thereby leading to a slight increase in its extraction percentage and causing a significant increase in the amount presented in the organic phase. The extraction of $\mathrm{Mg}^{2+}$ was $2.6 \%$, corresponding to $2.43 \mathrm{~g} \cdot \mathrm{L}^{-1}$ of $\mathrm{Mg}^{2+}$ in the organic phase at an $\mathrm{O} / \mathrm{A}$ ratio of $4: 1$, which was a much higher concentration than that of $\mathrm{Li}^{+}$ $(1.04 \mathrm{~g} / \mathrm{L})$. The extraction of $\mathrm{B}$ clearly increased with the increase in the $\mathrm{O} / \mathrm{A}$ ratio. However, its concentration in the organic phase was almost unchanged, only showing a very slight gradual decrease. Although further study is needed to explain the reason, it was most likely because a small amount of impurities in the organic phase could extract B. To obtain relatively high lithium extraction and loading in the organic phase, an $\mathrm{O} / \mathrm{A}$ ratio of 4:1 was selected as the optimum condition.

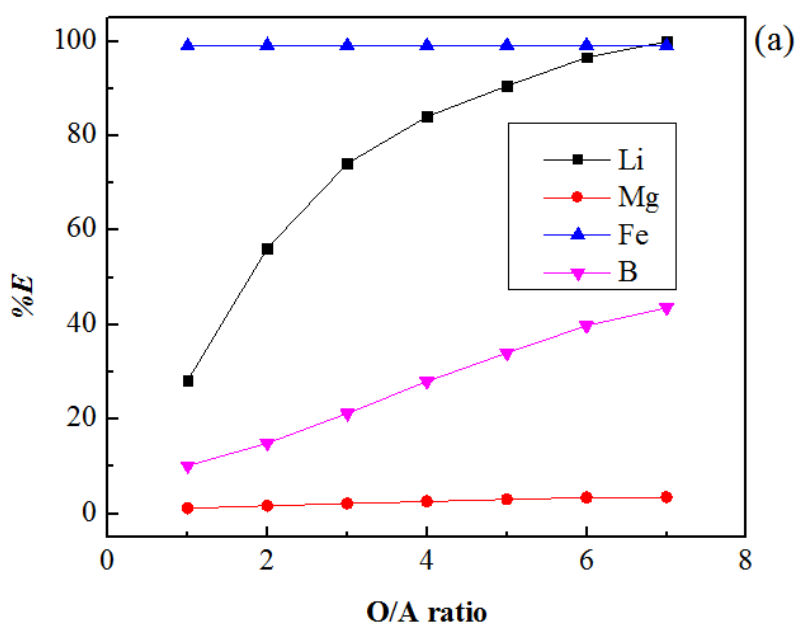




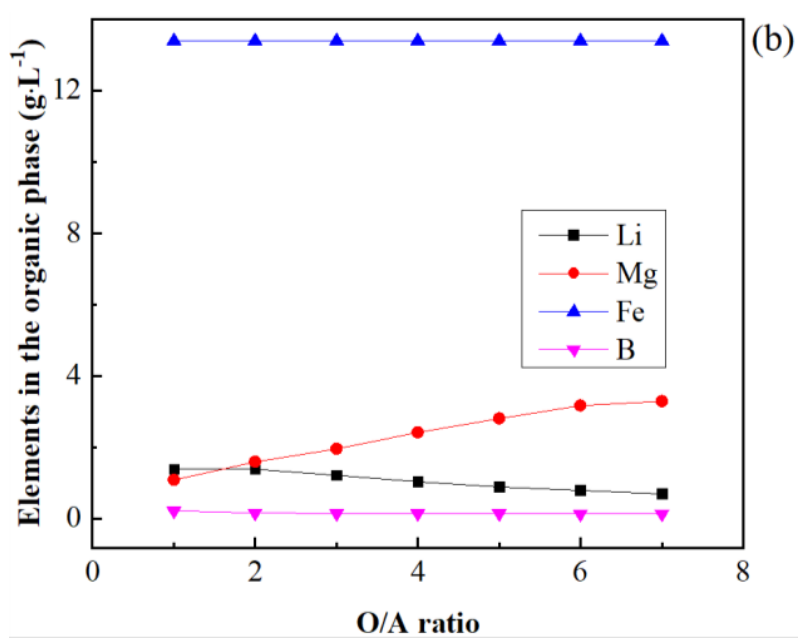

Fig. 5. Effect of the O/A ratio on the extraction of elements (a) and the elemental concentrations in the loaded organic phase (b).

\subsubsection{Effect of the temperature}

The effect of temperature on the lithium extraction from brine by a pre-loaded $\mathrm{Fe}^{3+}$ organic phase was conducted from $293-333 \mathrm{~K}$, as shown in Fig. $6 . \mathrm{Li}^{+}$extraction decreased with increasing temperature, and $\mathrm{B}$ extraction also decreased, while the extraction of $\mathrm{Fe}^{3+}$ and $\mathrm{Mg}^{2+}$ was almost unchanged. The enthalpy change $(\Delta \mathrm{H})$ of $\mathrm{Li}^{+}$extraction could be determined based on the slope of the $\log D_{\mathrm{Li}}$ versus $1 / T\left(10^{-3} \mathrm{~K}^{-1}\right)$ plot (Fig. 6) using the derived van't Hoff equation (Zhang et al., 2017a):

$$
\log D_{\mathrm{Li}}=-\frac{\Delta \mathrm{H}}{2.303 \mathrm{R} T}+\mathrm{C}
$$

where $\mathrm{R}$ is the universal gas constant and $\mathrm{C}$ is the integration constant. In this study, the integration constant was assumed to be constant at a particular temperature under the same experimental conditions.

The value of $\Delta \mathrm{H}$ of the extraction system was derived to be $-10.15 \mathrm{~kJ} / \mathrm{mol}$, suggesting 
the exothermic nature of the extraction reaction, which meant that a low temperature was preferential for the extraction of lithium. While considering the poor fluidity of the organic phase at low temperature and the difficulty in phase separation, the following experiments were conducted at room temperature $(293 \mathrm{~K})$.
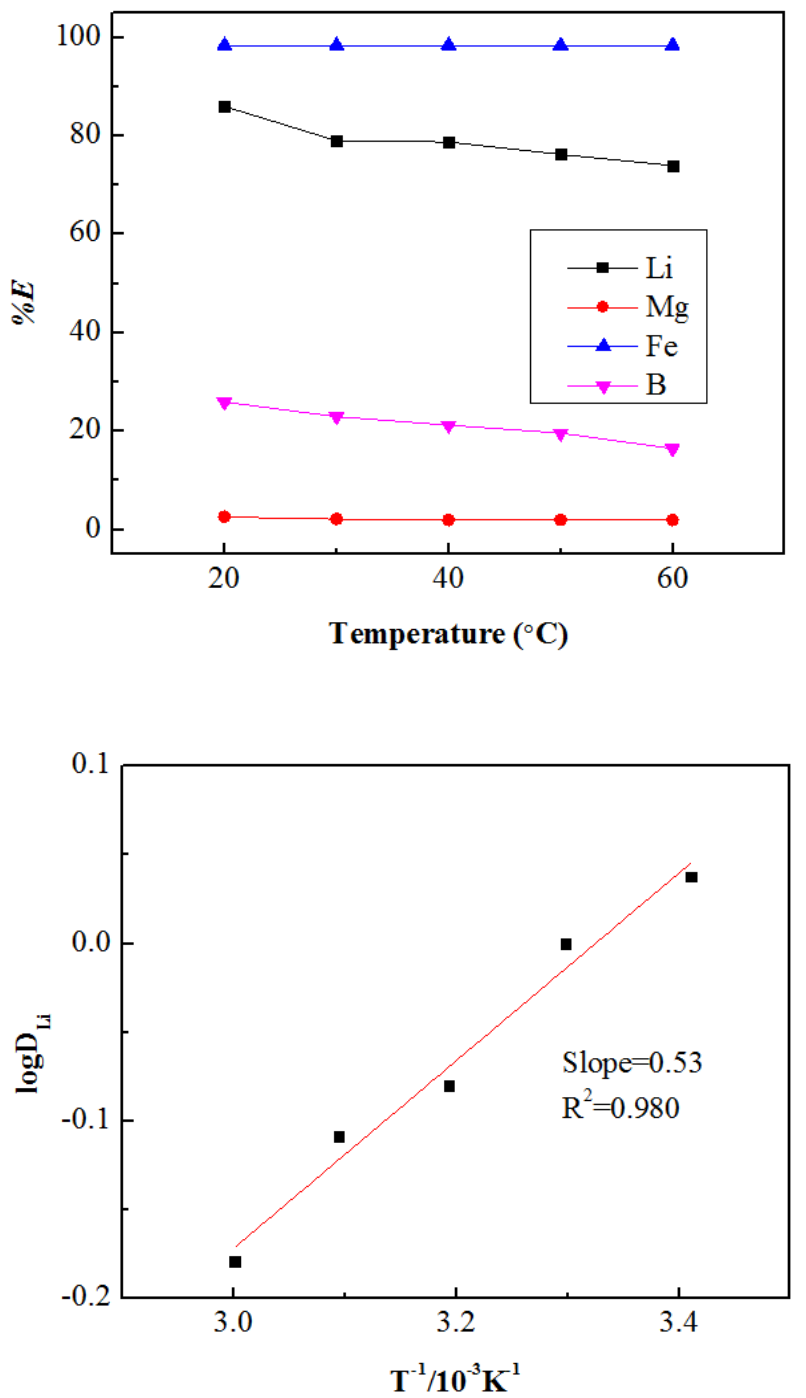

Fig. 6. Effect of the temperature on the extraction of elements.

\subsubsection{Effect of the shaking time}

The effect of shaking time on the lithium extraction from brine was investigated using a 
pre-loaded $\mathrm{Fe}^{3+}$ organic phase at an $\mathrm{O} / \mathrm{A}$ ratio of $4: 1$; the results are shown in Fig. 7. The $\mathrm{Li}^{+}$ extraction reached $82.3 \%$ in $1.0 \mathrm{~min}$ and then slowly increased to $85.5 \%$ in $5.0 \mathrm{~min}$. The extraction efficiencies of other elements changed slightly with shaking time. The lithium extraction was fast and reached equilibrium within $5.0 \mathrm{~min}$. Thus, a shaking time of $20 \mathrm{~min}$ was sufficient to reach extraction equilibrium.

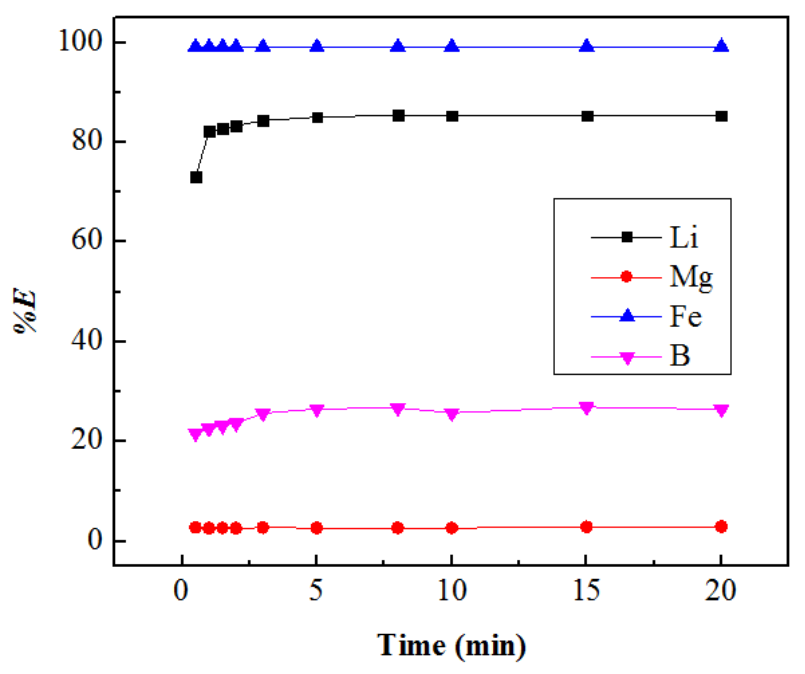

Fig. 7. Effect of the shaking time on the extraction of elements.

\subsection{Scrubbing}

The pre-loaded $\mathrm{Fe}^{3+}$ organic phase was mixed with brine for $\mathrm{Li}^{+}$extraction at an $\mathrm{O} / \mathrm{A}$ ratio of $4: 1$, a temperature of $20{ }^{\circ} \mathrm{C}$, and a shaking time of $20 \mathrm{~min}$. The obtained loaded organic phase containing $1.04 \mathrm{~g} \cdot \mathrm{L}^{-1} \mathrm{Li}^{+}, 13.35 \mathrm{~g} \cdot \mathrm{L}^{-1} \mathrm{Fe}^{3+}, 2.43 \mathrm{~g} \cdot \mathrm{L}^{-1} \mathrm{Mg}^{2+}$ and $0.17 \mathrm{~g} \cdot \mathrm{L}^{-1} \mathrm{~B}$ was scrubbed using water at different $\mathrm{O} / \mathrm{A}$ ratios, as shown in Fig. 8. With the increase in the $\mathrm{O} / \mathrm{A}$ ratio, the scrubbing efficiency of all elements decreased, and the concentration of elements in the organic phase increased. This result was mainly due to the increased concentration of $\mathrm{MgCl}_{2}$ in the scrub liquor, leading to a significant increase in the 
concentration of $\mathrm{Cl}^{-}$, which promoted the extraction of $\mathrm{Li}^{+}, \mathrm{Mg}^{2+}$ and $\mathrm{Fe}^{3+}$. As the extraction mechanism of $\mathrm{B}$ was different from that of the other metallic elements, the decrease in $\mathrm{B}$ scrubbing might be due to the increased B concentration in the scrub liquor, which promoted its transfer to the organic phase. When the $\mathrm{O} / \mathrm{A}$ ratio was $40: 1$, the scrubbing of $\mathrm{Mg}^{2+}$ remained at a high level of $74.4 \%$, and the concentration of $\mathrm{Cl}^{-}$in the scrub liquor was as high as $6 \mathrm{~mol} / \mathrm{L}$, which led to the scrubbing of $\mathrm{Li}^{+}$being only $3.4 \%$ and a low scrubbing of $\mathrm{Fe}^{3+}$. The scrubbed organic phase contained $1.01 \mathrm{~g} \cdot \mathrm{L}^{-1} \mathrm{Li}^{+}, 13.35 \mathrm{~g} \cdot \mathrm{L}^{-1} \mathrm{Fe}^{3+}, 0.64 \mathrm{~g} \cdot \mathrm{L}^{-1} \mathrm{Mg}^{2+}$ and $0.14 \mathrm{~g} \cdot \mathrm{L}^{-1} \mathrm{~B}$. Therefore, the $\mathrm{O} / \mathrm{A}$ ratio of $40: 1$ was selected as the optimum scrubbing phase ratio.
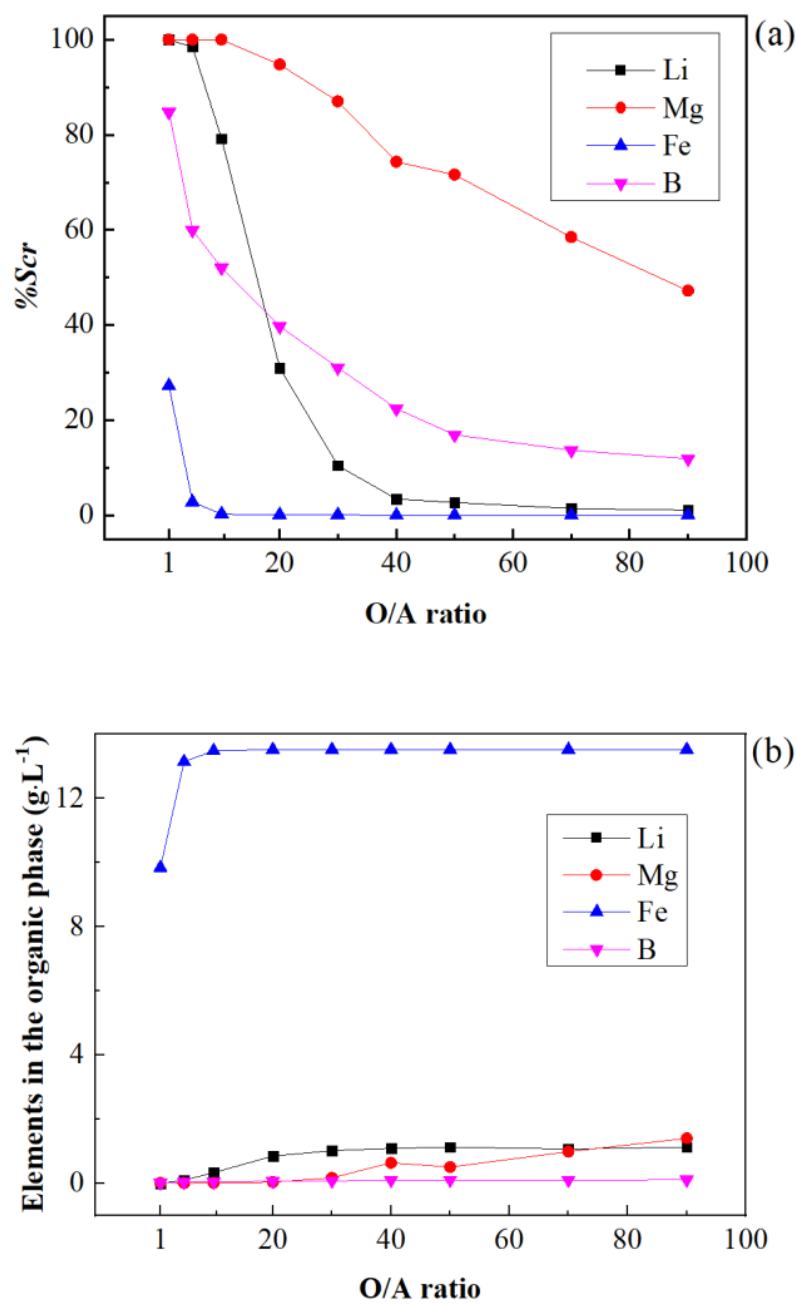
Fig. 8. Effect of the O/A ratio on the scrubbing (\%Scr) of elements (a) and the elemental concentrations in the organic phase (b).

\subsection{Stripping}

The effect of the $\mathrm{O} / \mathrm{A}$ ratio on the stripping of lithium using water was investigated using the scrubbed organic phase obtained at an optimum scrubbing $\mathrm{O} / \mathrm{A}$ ratio; the results are shown in Fig. 9. Similar to the scrubbing process, the stripping of elements decreased with an increasing $\mathrm{O} / \mathrm{A}$ ratio. The difference was that the $\mathrm{Li}^{+}$stripping was high at a high $\mathrm{O} / \mathrm{A}$ ratio. The stripping of $\mathrm{Li}^{+}$was $41.5 \%$ at an $\mathrm{O} / \mathrm{A}$ ratio of $40: 1$, while the scrubbing of $\mathrm{Li}^{+}$was only $3.4 \%$ at the same $\mathrm{O} / \mathrm{A}$ ratio. This result should be attributed to the fact that a large amount of $\mathrm{MgCl}_{2}$ in the organic phase was scrubbed by the following stripping step, and the concentration of $\mathrm{Cl}^{-}$in the strip liquor decreased to $4 \mathrm{~mol} / \mathrm{L}$, which made the stripping of lithium easier. The concentration of $\mathrm{Li}^{+}$in the strip liquor first increased and then decreased, reaching a maximum of $15.48 \mathrm{~g} \cdot \mathrm{L}^{-1}$ at an $\mathrm{O} / \mathrm{A}$ ratio of $40: 1 . \mathrm{Fe}^{3+}$ stably remained in the organic phase as it was slightly stripped with an $\mathrm{O} / \mathrm{A}$ ratio greater than 10 due to the synergistic extraction by TBP and P507 (Su et al., 2020a). $\mathrm{Mg}^{2+}$ stripping was more than 80\% over the whole range of phase ratios, but its concentration in the strip liquor gradually increased and exceeded $10 \mathrm{~g} \cdot \mathrm{L}^{-1}$ when the $\mathrm{O} / \mathrm{A}$ ratio was greater than 20 . The concentration of $\mathrm{B}$ in the strip liquor also gradually increased but remained near $2 \mathrm{~g} \cdot \mathrm{L}^{-1}$. To maintain $\mathrm{Fe}^{3+}$ in the organic phase and obtain high $\mathrm{Li}^{+}$stripping, an $\mathrm{O} / \mathrm{A}$ ratio of 20 was selected. The stripping of $\mathrm{Li}^{+}$and $\mathrm{Mg}^{2+}$ was 62.0 and $96.6 \%$, respectively, and their concentrations in the strip liquor were 11.57 and $12.33 \mathrm{~g} \cdot \mathrm{L}^{-1}$ at an $\mathrm{O} / \mathrm{A}$ ratio of 20 . Additionally, $\mathrm{Mg}^{2+}$ and $\mathrm{B}$ in the 
strip liquor were impurities that needed to be further removed by a multi-stage scrubbing and stripping procedure.
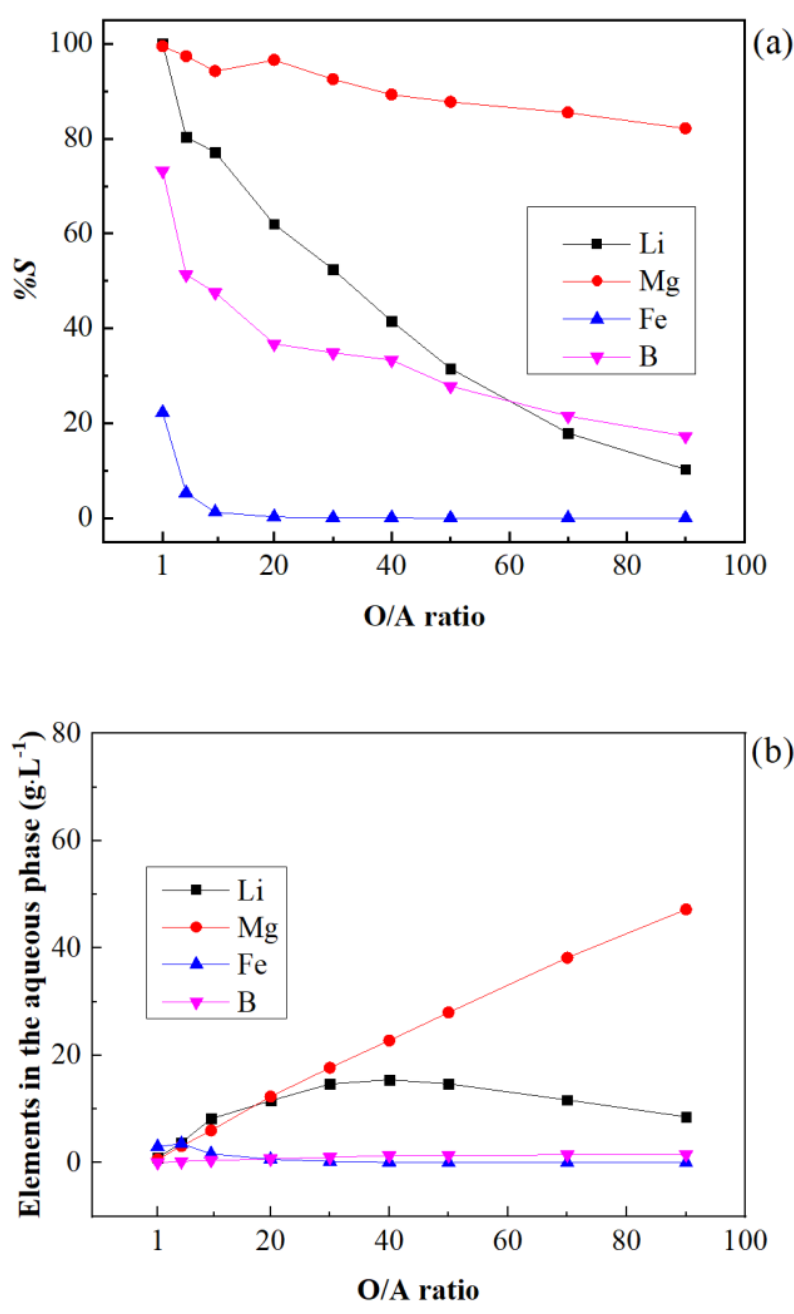

Fig. 9. Effect of the O/A ratio on the stripping of elements (a) and the elemental concentrations in the aqueous phase (b).

\subsection{Simulated counter-current process}

\subsubsection{Simulated counter-current extraction}

A multi-stage continuous counter-current extraction process was conducted to efficiently extract lithium from brine. The number of extraction stages was determined by the 
McCabe-Thiele diagram, as shown in Fig. 10. According to the above lithium extraction experiment at different phase ratios, the concentrations of $\mathrm{Li}^{+}$in the two phases at equilibrium were used to plot the equilibrium line. It was found that three theoretical stages were required to extract $\mathrm{Li}^{+}$more completely from the brine at an $\mathrm{O} / \mathrm{A}$ ratio of 4:1. Eleven series of batch-row contact of the three-stage counter-current extraction was conducted to reach extraction equilibrium (Fig. 1), and the results are shown in Table 6. It was found that $99.8 \%$ of $\mathrm{Li}^{+}$in the brine was extracted through the three-stage counter-current extraction, and the concentration of $\mathrm{Li}^{+}$in the loaded organic phase was $1.41 \mathrm{~g} \cdot \mathrm{L}^{-1}$. The $\mathrm{Fe}^{3+}$ extraction was $100 \%$ with no $\mathrm{Fe}^{3+}$ found in the raffinate. Additionally, there were $2.43 \mathrm{~g} \cdot \mathrm{L}^{-1} \mathrm{Mg}^{2+}$ and $0.21 \mathrm{~g} \cdot \mathrm{L}^{-1} \mathrm{~B}$ in the loaded organic phase, which needed to be further removed by scrubbing.

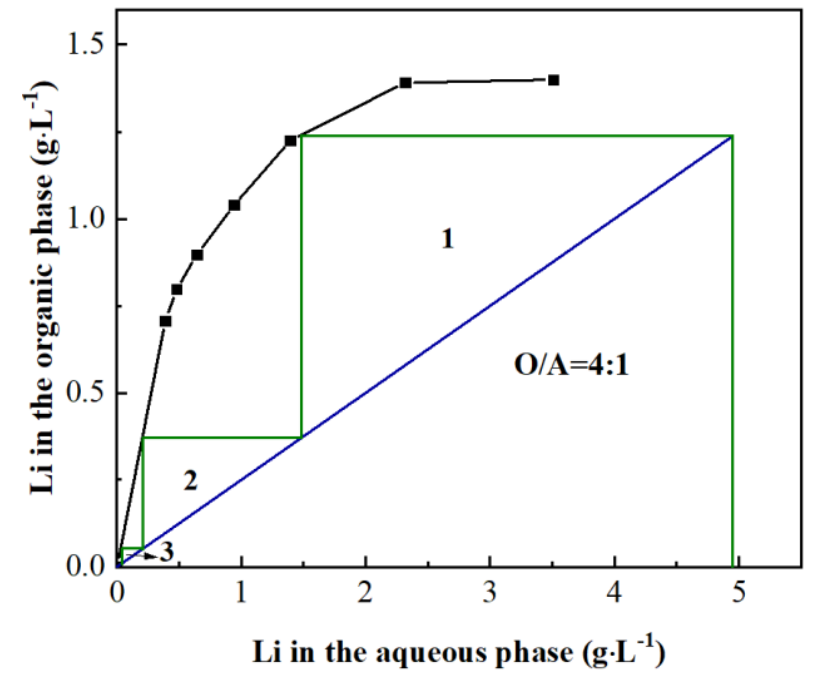

Fig. 10. McCabe-Thiele diagram to determine the number of extraction stages.

Table 6. Results of the three-stage counter-current extraction.

\begin{tabular}{cccccc}
\hline & $\mathrm{Li}^{+}$ & $\mathrm{Fe}^{3+}$ & $\mathrm{Mg}^{2+}$ & $\mathrm{B}$ & $\mathrm{H}^{+}$ \\
\hline $\begin{array}{c}\text { Concentration in the } \\
\text { saturated } \mathrm{MgCl}_{2} \text { solution }\end{array}$ & $/$ & 13.39 & 108.23 & $/$ & 0.43 \\
\hline
\end{tabular}




\begin{tabular}{|c|c|c|c|c|c|}
\hline$\left(\mathrm{g} \cdot \mathrm{L}^{-1}\right)$ & & & & & \\
\hline $\begin{array}{l}\text { Concentration in the } \\
\text { brine }\left(\mathrm{g} \cdot \mathrm{L}^{-1}\right)\end{array}$ & 5.02 & l & 108.10 & 2.23 & 0.14 \\
\hline $\begin{array}{l}\text { Concentration in the } \\
\text { raffinate }\left(\mathrm{g} \cdot \mathrm{L}^{-1}\right)\end{array}$ & 0.01 & l & 98.60 & 1.48 & 0.01 \\
\hline $\begin{array}{l}\text { Concentration in the } \\
\text { loaded organic phase } \\
\qquad\left(\mathrm{g} \cdot \mathrm{L}^{-1}\right)\end{array}$ & 1.41 & 13.39 & 2.43 & 0.21 & l \\
\hline Extraction $(\%)$ & 99.82 & 100 & 2.76 & 33.86 & l \\
\hline
\end{tabular}

\subsubsection{Simulated counter-current scrubbing}

The loaded organic phase obtained by the three-stage counter-current extraction was scrubbed by water to remove impurities. According to the scrubbing experiment at different phase ratios, the number of scrubbing stages was determined by the McCabe-Thiele diagram, as shown in Fig. 11, and the concentrations of $\mathrm{Mg}^{2+}$ in the two phases at equilibrium were used to plot the equilibrium line. It was found that three theoretical stages were required to efficiently scrub $\mathrm{Mg}^{2+}$ from the loaded organic phase at an O/A ratio of 40:1. Eleven series of batch-row contact of the three-stage counter-current scrubbing was conducted to reach scrubbing equilibrium, and the results are shown in Table 7 . It was found that $95.8 \%$ of the $\mathrm{Mg}^{2+}$ in the loaded organic phase was scrubbed through the three-stage counter-current scrubbing, and the concentration of $\mathrm{Mg}^{2+}$ in the scrubbed organic phase was $0.14 \mathrm{~g} \cdot \mathrm{L}^{-1}$. The loss of $\mathrm{Li}^{+}$was only $2.1 \%$, and the concentration of $\mathrm{Li}^{+}$in the scrubbed organic phase was $1.31 \mathrm{~g} \cdot \mathrm{L}^{-1}$. Moreover, $\mathrm{Fe}^{3+}$ was not detected in the scrub liquor. The scrubbing of $\mathrm{B}$ was $20.4 \%$, and its concentration in the scrubbed organic phase was $0.17 \mathrm{~g} \cdot \mathrm{L}^{-1}$. Thus, the scrub liquor could be recycled for use in the extraction step of the next extraction cycle. 


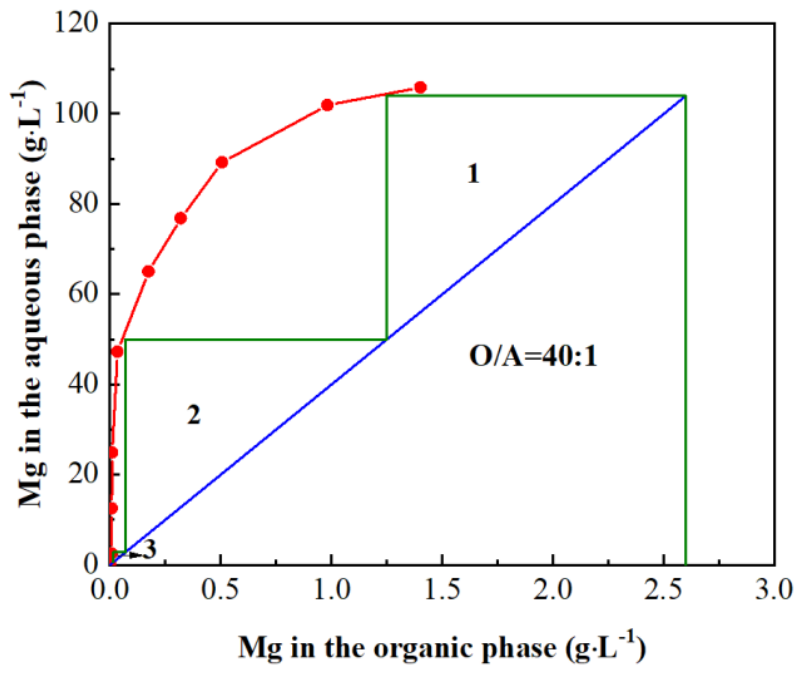

Fig. 11. McCabe-Thiele diagram to determine the number of scrubbing stages.

Table 7. Results of the three-stage counter-current scrubbing.

\begin{tabular}{cccccc}
\hline & $\mathrm{Li}^{+}$ & $\mathrm{Fe}^{3+}$ & $\mathrm{Mg}^{2+}$ & $\mathrm{B}$ & $\mathrm{H}^{+}$ \\
\hline $\begin{array}{c}\text { Concentration in the } \\
\text { loaded organic phase } \\
\quad\left(\mathrm{g} \cdot \mathrm{L}^{-1}\right)\end{array}$ & 1.41 & 13.39 & 2.43 & 0.21 & $/$ \\
$\begin{array}{c}\text { Concentration in the } \\
\text { scrub liquor }\left(\mathrm{g} \cdot \mathrm{L}^{-1}\right)\end{array}$ & 1.20 & $/$ & 93.10 & 1.72 & 0.02 \\
$\begin{array}{c}\text { Concentration in the } \\
\text { scrubbed organic phase } \\
\quad\left(\mathrm{g} \cdot \mathrm{L}^{-1}\right)\end{array}$ & 1.31 & 13.39 & 0.14 & 0.17 & $/$ \\
$\quad$\begin{tabular}{c} 
Scrubbing $(\%)$ \\
\hline
\end{tabular} & 2.13 & 0.00 & 95.78 & 20.45 & $/$ \\
\hline
\end{tabular}

\subsubsection{Simulated counter-current stripping}

The scrubbed organic phase obtained by the three-stage counter-current scrubbing was subjected to a stripping step by water. According to the stripping experiment at different phase ratios, the number of stripping stages was determined by the McCabe-Thiele diagram, as shown in Fig. 12, and the concentrations of $\mathrm{Li}^{+}$in the two phases at equilibrium were used to plot the equilibrium line. It was found that three theoretical stages were required to 
completely strip $\mathrm{Li}^{+}$from the scrubbed organic phase at an $\mathrm{O} / \mathrm{A}$ ratio of $16: 1$. Eleven series of batch-row contact of the three-stage counter-current stripping was conducted to reach stripping equilibrium, and the results are shown in Table 8 . It was found that $99.8 \%$ of the $\mathrm{Li}^{+}$ in the scrubbed organic phase was stripped through the three-stage counter-current stripping, and the concentration of $\mathrm{Li}^{+}$in the strip liquor was $20.92 \mathrm{~g} \cdot \mathrm{L}^{-1} \cdot \mathrm{Fe}^{3+}$ was hardly stripped because no $\mathrm{Fe}^{3+}$ was detected in the strip liquor. The stripping values of $\mathrm{Mg}^{2+}$ and $\mathrm{B}$ were 99.6 and $59.1 \%$, respectively, and their concentrations in the strip liquor were 2.23 and 1.61 $\mathrm{g} \cdot \mathrm{L}^{-1}$, respectively. Compared with the single-stage strip liquor, the concentration of $\mathrm{Mg}^{2+}$ in the three-stage counter-current strip liquor largely decreased, while the concentration of B was still approximately $1 \mathrm{~g} \cdot \mathrm{L}^{-1}$. However, the preparation of battery-grade lithium products would require the further removal of impurities in the strip liquor, which will be investigated in our next study. Because there was almost no loss of $\mathrm{Fe}^{3+}$ in the organic phase, the organic phase could be reused directly for the next extraction cycle without regeneration. The above nine-stage simulated counter current process avoided the third phase and did not lose extractants.

The operating cost (including the reagents, power consumption, personnel and transportation) of this novel mixed ternary system for lithium extraction from a treated East Tajinar Salt Lake brine was estimated. While it is assumed to produce $1000 \mathrm{t} / \mathrm{year}$ of industrial grade $\mathrm{Li}_{2} \mathrm{CO}_{3}$ (purity $>99 \%$ ), the production cost of $\mathrm{Li}_{2} \mathrm{CO}_{3}$ is less than CNY20,000/t (around USD2,924). Therefore, this novel system has strong market competitiveness and broad prospects for use in industrial application. 


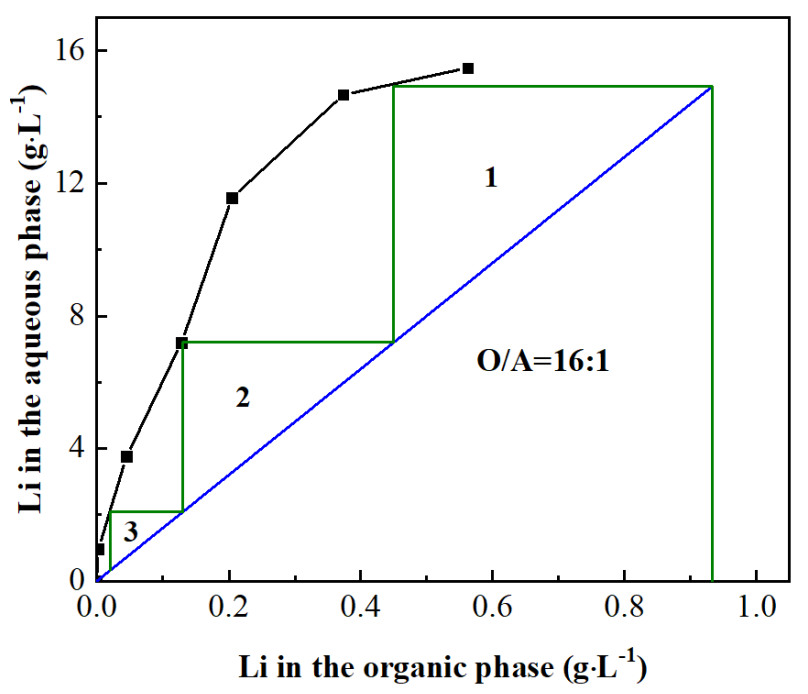

Fig. 12. McCabe-Thiele diagram to determine the number of stripping stages.

Table 8. Results of the three-stage counter-current stripping.

\begin{tabular}{cccccc}
\hline & $\mathrm{Li}^{+}$ & $\mathrm{Fe}^{3+}$ & $\mathrm{Mg}^{2+}$ & $\mathrm{B}$ & $\mathrm{H}^{+}$ \\
\hline $\begin{array}{c}\text { Concentration in the } \\
\text { scrubbed organic phase } \\
\left(\mathrm{g} \cdot \mathrm{L}^{-1}\right)\end{array}$ & 1.31 & 13.39 & 0.14 & 0.17 & $/$ \\
$\begin{array}{c}\text { Concentration in the } \\
\text { stripped organic phase } \\
\quad\left(\mathrm{g} \cdot \mathrm{L}^{-1}\right)\end{array}$ & 0.09 & 13.39 & 0.00 & 0.04 & $/$ \\
$\begin{array}{c}\text { Concentration in the } \\
\text { strip liquor }\left(\mathrm{g} \cdot \mathrm{L}^{-1}\right)\end{array}$ & 20.92 & 0.00 & 2.23 & 1.61 & 0.30 \\
$\quad$ Stripping $(\%)$ & 99.81 & 0.00 & 99.55 & 59.08 & $/$ \\
\hline
\end{tabular}

\section{Conclusions}

Lithium recovery from a treated East Tajinar Salt Lake brine by using a mixed ternary solvent extraction system of $\mathrm{TBP} / \mathrm{FeCl}_{3} / \mathrm{P} 507$ was studied. Various extraction conditions were investigated, and the optimum conditions were determined as $14 \mathrm{~g} \cdot \mathrm{L}^{-1}$ of pre-loaded $\mathrm{Fe}^{3+}$ in an organic phase containing 40 vol\% TBP and 30 vol\% P507 in kerosene with an O/A ratio of $1: 1$. Then, the pre-loaded $\mathrm{Fe}^{3+}$ organic phase was mixed with brine for $\mathrm{Li}^{+}$extraction at an 
$\mathrm{O} / \mathrm{A}$ ratio of $4: 1$. After a three-stage extraction, $99.8 \%$ of $\mathrm{Li}^{+}$was recovered. The loaded organic phase was scrubbed by water in three stages, resulting in an organic phase containing $\left(\mathrm{g} \cdot \mathrm{L}^{-1}\right): \mathrm{Li}^{+}, 1.31 ; \mathrm{Mg}^{2+}, 0.14 ; \mathrm{B}, 0.17$; and no loss of $\mathrm{Fe}^{3+}$. The scrubbed organic phase was further stripped by water in three stages, leading to a strip liquor containing $\left(g \cdot \mathrm{L}^{-1}\right)$ : $\mathrm{Li}, 20.9$; $\mathrm{Mg}, 2.2 ; \mathrm{B}, 1.6 ; \mathrm{H}, 0.3$; and no loss of $\mathrm{Fe}^{3+}$. The stripped organic phase was readily reusable without regeneration. The nine-stage simulated counter-current process exhibited a high $\mathrm{Li} / \mathrm{Mg}$ selectivity, high lithium recovery rate, and efficient lithium stripping by water; therefore, this process is a key step forward for the sustainable recovery of lithium from salt lake brines with a high $\mathrm{Mg}$ content.

\section{Declaration of Competing Interest}

The authors declare no competing financial interest.

\section{Acknowledgements}

This work was supported by the National Natural Science Foundation of China (51774260, 51804289, 51904286, 21908231), the National Key R\&D Programme of China (2018YFC1900500), the Key Research Programme of Frontier Sciences of the Chinese Academy of Sciences (QYZDJ-SSW-JSC021), Beijing Natural Science Foundation (2202053), the CAS Interdisciplinary Innovation Team and the China Postdoctoral Science

Foundation 2019M650848. Zheng Li was supported by the Senior FWO Postdoctoral Fellowship (181203/12Z1920N).

\section{References}


U.S. Geological Survey. Mineral commodity summaries 2019: U.S. Geological Survey., 200p, https://www.usgs.gov.

Cengeloglu, Y., Tor, A., Arslan, G., Ersoz, M. Gezgin, S., 2007. Removal of boron from aqueous solution by using neutralized red mud. J. Hazard. Mater. 142(1-2), 412-417.

Etacheri, V., Marom, R., Elazari, R., Salitra, G. Aurbach, D., 2011. Challenges in the development of advanced Li-ion batteries: a review. Energy Environ. Sci. 4, $3243-3262$.

Gao, D., Yu, X., Guo, Y., Wang, S. Nelson, B., 2015. Extraction of lithium from salt lake brine with triisobutyl phosphate in ionic liquid and kerosene. Chem. Res. Chin. Univ. 31(4), 621-626.

Guo, X., Hu, S., Wang, C., Duan, H. Xu, X., 2018a. Highly efficient separation of magnesium and lithium and high-valued utilization of magnesium from salt lake brine by a reaction-coupled separation technology. Ind. Eng. Chem. Res. 57, 6618-6626.

Guo, Z., Ji, Z., Chen, Q., Liu, J., Zhao, Y., Li, F., Liu, Z. Yuan, J., 2018b. Prefractionation of $\mathrm{LiCl}$ from concentrated seawater/salt lake brines by electrodialysis with monovalent selective ion exchange membranes. J. Clean Prod. 193, 338-350.

Kesler, S.E., Gruber, P.W., Medina, P.A., Keoleian, G.A., Everson, M.P. Wallington, T.J., 2012. Global lithium resources: Relative importance of pegmatite, brine and other deposits. Ore Geol. Rev. 48, 55-69. 
Kuz'min, V. Gudkova, N., 2015. Extraction of lithium using TBP and the noncoordinating cation exchanger tetraphenylborate: principles of selectivity from sodium and higher-valent cations. Solvent Extr. Ion Exch. 33, 183-195.

Li, R. Liu, F., 2017. Extracting lithium from salt lake brine via adsorption method. Modern Chemical Industry 37(8), 132-134.

Li, Y., Song, J. Yang, J., 2014. A review on structure model and energy system design of lithium-ion battery in renewable energy vehicle. Renew. Sust. Energ. Rev. 37, $627-633$.

Li, Y., Zhao, Z., Liu, X., Chen, X. Zhong, M., 2015. Extraction of lithium from salt lake brine by aluminum-based alloys. Trans. Nonferrous Met. Soc. China 25(10), 3484-3489.

Li, Z., Mercken, J., Li, X., Riaño, S.a. Binnemans, K., 2019. Efficient and sustainable removal of magnesium from brines for lithium/magnesium separation using binary extractants. ACS Sustain. Chem. Eng. 7, 19225-19234.

Nelli, J.R., Arthur, T.E. Gastonia, J., 1970. Recovery of lithium from bitterns. US patent. No. US3537813DA.

Pakalns, P., 1981. Potentiometric titration of free acid in salt solutions after addition of potassium oxalate as a complexing agent. Anal. Chim. Acta 127, 263-269.

Ren, S., Zeng, Y., Li, L. Peng, S., 2013. Development Progress on the Extraction of Lithium from Salt Lake Brines. Guangzhou Chemical Industry 41(1), 36-50. 
Shi, C., Jia, Y., Zhang, C., Liu, H. Jing, Y., 2015. Extraction of lithium from salt lake brine using room temperature ionic liquid in tributyl phosphate. Fusion Eng. Des. 90, 1-6.

Shi, D., Cui, B., Li, L., Peng, X., Zhang, L. Zhang, Y., 2019a. Lithium extraction from low-grade salt lake brine with ultrahigh $\mathrm{Mg} / \mathrm{Li}$ ratio using $\mathrm{TBP}-\mathrm{kerosene}-\mathrm{FeCl}_{3}$ system. Sep. Purif. Technol. 211, 303-309.

Shi, D., Cui, B., Li, L., Peng, X., Zhang, L. Zhang, Y., 2019b. Lithium extraction from low-grade salt lake brine with ultrahigh $\mathrm{Mg} / \mathrm{Li}$ ratio using $\mathrm{TBP}$ - kerosene $-\mathrm{FeCl}_{3}$ system. Sep. Purif. Technol. 211, 303-309.

Shi, D., Zhang, L., Peng, X., Li, L., Song, F., Nie, F., Ji, L. Zhang, Y., 2018. Extraction of lithium from salt lake brine containing boron using multistage centrifuge extractors. Desalination 441, 44-51.

Song, J., Long, D., Li, X. He, T., 2017a. Lithium extraction from Chinese salt-lake brines: opportunities, challenges, and future outlook. Environ. Sci.-Wat. Res. Technol. 3(4), 593-597.

Song, J., Tao, H., Qiu, H., Li, X. Tao, H., 2017b. Recovery of lithium from salt lake brine of high $\mathrm{Mg} / \mathrm{Li}$ ratio using $\mathrm{Na}\left[\mathrm{FeCl}_{4} * 2 \mathrm{TBP}\right]$ as extractant: Thermodynamics, kinetics and processes. Hydrometallurgy 173, 63-70.

Starke, K., 1963. Iodometric titration of free acid in iron(III) solutions and determination of basic iron(III) compounds. Anal. Chem. 35(9), 1310-1311. 
Su, H., Li, Z., Zhang, J., Liu, W., Zhu, Z., Wang, L. Qi, T., 2020a. Combining selective extraction and easy stripping of lithium using a ternary synergistic solvent extraction system through regulation of $\mathrm{Fe}^{3+}$ coordination. ACS Sustain. Chem. Eng. 8, 1971-1979.

Su, H., Li, Z., Zhu, Z., Wang, L. Qi, T., 2020b. Extraction relationship of $\mathrm{Li}^{+}$and $\mathrm{H}^{+}$using tributyl phosphate in the presence of Fe(III). Sep. Sci. Technol. 55(9), 1677-1685.

Swain, B., 2017. Recovery and recycling of lithium: a review. Sep. Purif. Technol. 172, $388-403$.

Wang, Y., Liu, H., Fan, J., Liu, X., Hu, Y., Hu, Y., Zhou, Z. Ren, Z., 2019. Recovery of lithium ions from salt lake brine with a high magnesium/lithium ratio using heteropolyacid ionic liquid. ACS Sustain. Chem. Eng. 7, 3062-3072.

Xiang, W., Liang, S., Zhou, Z., Qin, W. Fei, W., 2016. Extraction of lithium from salt lake brine containing borate anion and high concentration of magnesium. Hydrometallurgy $166,9-15$.

Xiang, W., Liang, S., Zhou, Z., Qin, W. Fei, W., 2017. Lithium recovery from salt lake brine by counter-current extraction using tributyl phosphate $/ \mathrm{FeCl}_{3}$ in methyl isobutyl ketone. Hydrometallurgy 171, 27-32.

Yu, J., Gao, C., Cheng, A., Liu, Y., Zhang, L. He, X., 2013. Geomorphic, hydroclimatic and hydrothermal controls on the formation of lithium brine deposits in the Qaidam Basin, northern Tibetan Plateau, China. Ore Geol. Rev. 50, 171-183. 
Zhang, L., Li, L., Dong, S., Li, J., Peng, X. Feng, N., 2017a. Selective extraction of lithium from alkaline brine using HBTA-TOPO synergistic extraction system. Sep. Purif. Technol. 188, 167-173.

Zhang, X., Tan, X. Zhang, L., 2017b. Research progress in lithium extraction from salt lake brine by nanofiltration membrane separation technology. Inorganic Chemicals Industry 49(1), 1-5.

Zhang, Y., Li, L., Li, J., Ji, L., Xu, Q. Chen, G., 2012. Study on mechanism of extraction of lithium from salt lake brine by tributylphosphate. Inorg Chem ind 44(3), 12-15.

Zhou, Z., Fan, J., Liu, X., Hu, Y., Wei, X., Hu, Y., Wang, W. Ren, Z., 2020. Recovery of lithium from salt-lake brines using solvent extraction with TBP as extractant and $\mathrm{FeCl}_{3}$ as co-extraction agent. Hydrometallurgy 191, 1-8.

Zhou, Z., Qin, W., Chu, Y. Fei, W., 2013. Elucidation of the structures of tributyl phosphate/Li complexes in the presence of $\mathrm{FeCl}_{3}$ via $\mathrm{UV}$-visible, Raman and IR spectroscopy and the method of continuous variation. Chem. Eng. Sci. 101(20), $577-585$.

Zhou, Z., Qin, W., Fei, W. Li, Y., 2012. A study on stoichiometry of complexes of tributyl phosphate and methyl isobutyl ketone with lithium in the presence of $\mathrm{FeCl}_{3}$. Chin. J. Chem. Eng. 20(1), 36-39. 